\title{
PENGARUH SIKAP DAN NORMA SUBYEKTIF TERHADAP NIAT BELI MASYARAKAT SEBAGAI KONSUMEN BIG TV PADA KELURAHAN SEI AGUL KECAMATAN MEDAN BARAT
}

\author{
Oleh: \\ Darna Sitanggang, SE, M.Si
}

\begin{abstract}
The rise of information technology today, resulted in viewers want more information forms from abroad in the form of news and entertainment shows. The need for more extensive information, an opportunity for the satellite television station. Satellite TV is not to compete with each other is BIG TV, which is one of the satellite TV channel highest and the lowest in Indonesia, both SD (standard definition) and HD (high definition), while becoming a satellite TV pay-first serving HD channels more lots for its customers. From the description, the problem in this research is formulated as follows: "Is the consumer attitudes and subjective norms significantly influence consumer intentions to buy BIG TV on agul Sei Village West district of Medan."

This study aimed to analyze the influence of consumer attitudes, subjective norms influence on consumer intentions to buy BIG TV and to know how consumer intentions to buy BIG TV on agul Sei Village West district of Medan. The benefits of research is to give an overview of consumer attitudes and subjective norms on consumer intentions to buy BIG TV on agul Sei Village West district of Medan. The study population was Sei agul community in the Village West district of Medan. Samples were taken 96 people. The required data were collected using a questionnaire. Data analysis technique used is descriptive method by using the theory of planned behavior.

From the discussion concluded that the average value of the consumer attitude variables (Ab) of 2.42. That is, the public / consumer in the village of Sei agul be positive (very strong) against BIG TV. The average value of the variable subjective norm (SN) of 0.32. That is, the public / consumer in the village of Sei agul convinced and got positive motivation (strong enough) of the group preferred to subscribe BIG TV. Behavioral intention equation: $B I=$ $0,8229 A b+0,1770 S N$. Behavior public / consumer in the village of Sei agul to subscribe BIG TV is more influenced by consumer attitudes that is equal to 0.8229 (82.29\%) compared to the subjective norm, amounting to 0.1770 (17.70\%). Advice given to the management of BIG TV is that companies provide more training earnestly to marketers, giving higher incentives so that they are more spirit in introducing and providing services to customers and to the community $B I G T V$.
\end{abstract}

\section{PENDAHULUAN}

Pada persaingan pasar global dewasa ini banyak sekali barang dan jasa yang bermunculan di pasaran. Pasar global telah diramaikan dengan berbagai produk barang dan jasa untuk menarik perhatian konsumen. Dalam sebuah pasar global tentu saja terjadi persaingan antara produsen dengan merek masing-masing untuk memikat konsumen. Persaingan pasar global merupakan situasi dimana banyak bermunculan para produsen sedangkan konsumen sangat kritis dan pintar dalam memilih produk. Konsumen akan membeli produk apapun asalkan produk tersebut bagus, berkualitas dan harganya terjangkau. Dalam persaingan bisnis yang semakin ketat, setiap perusahaan dituntut untuk mampu mempelajari perilaku konsumen sebagai dasar penentuan strategi pemasaran. Dari perilaku konsumen, akan diketahui keinginan dan kebutuhan konsumen 
yang selanjutnya digunakan sebagai dasar untuk menyediakan alat pemuas kebutuhan dan menyampaikannya ke pasar.

Indonesia merupakan Negara yang mempunyai penduduk terbesar ke empat di dunia dengan jumlah penduduk pada bulan Juli 2014 diperkirakan mencapai 252 juta jiwa. Tidak mengherankan apabila dengan jumlah penduduk sebesar ini, Indonesia merupakan salah satu target pasar yang paling menarik untuk digarap oleh produsen khususnya para operator TV baik Stasiun TV lokal dan nasional yang dapat disaksikan secara gratis (Free To Air) maupun Stasiun TV berlangganan (Pay TV) yang akan dikenakan biaya berlangganan setiap bulannya. Pada dasarnya fungsi televisi adalah sebagai alat media massa elektronik yang dipergunakan oleh pemilik atau pemanfaat untuk memperoleh sejumlah informasi, hiburan, pendidikan dan sebagainya (www.seputar televisi.blogspot.com).

Saat ini sudah terdapat 10 Stasiun TV nasional dan lebih dari 50 Stasiun TV lokal yang beroperasi di Indonesia. Bertumbuhnya stasiun TV lokal maupun nasional (Free To Air) yang dapat disaksikan secara gratis ternyata tidak diikuti oleh peningkatan ragam tayangan yang disajikan. Para operator TV lokal tersebut menawarkan tayangan-tayangan yang hampir serupa pada semua acaranya, disamping jumlah stasiun TV lokal (Free To Air) yang terbatas. Hal ini mengakibatkan pemirsa merasa tidak memiliki jenis tontonan lainnya yang dapat dinikmati dan mengharuskan mereka mengikuti program acara yang ada. Sebagai imbasnya adalah pemirsa akan cepat merasa jenuh terhadap bentuk tayangan stasiun TV lokal.

Kondisi lainnya adalah semakin meningkatnya teknologi informasi saat ini, mengakibatkan pemirsa menginginkan bentuk informasi lainnya dari luar negeri baik dalam bentuk tayangan berita maupun hiburan. Kebutuhan terhadap informasi yang lebih luas dalam hal ini adalah tayangan dari stasiun TV di luar negeri, maka akan memberikan kebebasan kepada pemirsanya untuk memiliki pilihan tayangan TV yang cukup banyak. Hadirnya operator Pay TV di Indonesia, memberikan alternatif baru bagi para pemirsa untuk memilih acara-acara yang menarik yang ditawarkan seperti $H B O$, ESPN, Fashion TV, Discovery Channel, CNN, dan lain-lain. Pay TV juga menawarkan kenyamanan lebih dalam menonton TV dengan tidak adanya jeda iklan di sela-sela tayangan yang disajikan.

Mengingat tingkat persaingan stasiun televisi yang terus meningkat yang ditandai dengan munculnya operator TV baru, maka produsen perlu untuk menyelami lebih jauh tentang karakteristik konsumen mereka. Dalam hal ini, produsen perlu bertindak sebagai konsumen untuk mengetahui benar apa yang diinginkan oleh konsumennya. Salah satu kunci sukses untuk menarik minat komsumen adalah pengembangan produk dan promosi yang sesuai dengan kebutuhan target pasar. Dengan demikian produk yang berhasil adalah produk yang dapat diterima konsumen dengan harga, atribut dan tampilan yang memenuhi kebutuhan konsumen. Untuk itu produsen perlu mengetahui bagaimana konsumen memandang produk-produk dan progam pemasarannya.

Untuk saat ini, penetrasi dari layanan Pay TV masih relatif rendah dibandingan dengan jumlah pengguna potensial yang ada di pasar. Menurut Rudy Tanoesoedibjo, Direktur Utama Indovision, pasar potensial pelanggan TV berlangganan (baik kabel maupun satelit) ada 12 juta orang. Mereka adalah sekitar 22\% dari total 54 juta pemilik TV rumahan di Indonesia pada saat ini. Gambaran ini juga diperoleh dari beberapa tulisan di media yaitu diantaranya adalah http://www.antara.co.id/arc/2007/12/18/ sejumlah-pemain-baru-tv-bersaing-rebut-pasar danhttp://www.kompas.com/kompascetak.php/read/xml/2008/04/27/01211575/riuhnya.persai ngan.televisi.berbayar. Sedangkan jumlah pelanggan pay TV di Indonesia sampai dengan bulan November 2014 diprediksi mencapai 3.000.000 pelanggan. Berdasarkan data tersebut, potensi pasar yang dapat dikembangkan oleh para operator pay TV berlangganan masih terbuka dengan lebar. Tidak heran jika masing-masing operator menerapkan berbagai macam strategi andalan untuk menarik pelanggan sebanyak-banyaknya. Sebagian operator TV berlangganan menawarkan paket dengan harga murah, pemberian discount selama beberapa bulan, pemberian decoder gratis, bahkan 
ada yang mempromosikan bahwa program acaranya dapat membuat seorang anak menjadi pintar sebagai salah satu bentuk strategi pemasarannya.

Perilaku konsumen merupakan tindakan yang langsung terlibat dalam mendapatkan, mengkonsumsi, serta menghabiskan produk dan jasa, termasuk proses keputusan yang mendahului dan menyusuli tindakan tersebut. Perilaku pembelian seseorang dapat dikatakan sesuatu yang unik, karena preferensi dan sikap setiap orang terhadap obyek berbeda. Selain itu konsumen berasal dari beberapa segmen, sehingga apa yang dibutuhkan dan diinginkan juga berbeda. Untuk memahami bagaimana hubungan antara sikap dan perilaku, telah dikembangkan beberapa teori antara lain Theory of Reasoned Action (TRA), Theory of Planned Behavior (TPB), dan Theory of Trying (TT). Penelitian ini hanya fokus pada aplikasi Theory of Reasoned Action(TRA).

Pada saat ini, TV satelit sangat digemari karena memiliki channel yang cukup banyak. Seperti diuraikan di atas, bahwa perilaku pembelian setiap orang adalah sesuatu yang unik. Untuk acara televisi misalnya, ada yang senang dengan tayangan olahraga terutama bola, ada yang senang film, berita, musik, lawak dan lain sebagainya. Oleh karena itu, para operator TV satelit harus mempelajari dengan cermat perilaku konsumen, sehingga mereka mengetahui acara-acara apa saja yang perlu mereka siarkan sehingga pemirsa dapat menonton acara kesayangan masing-masing.

Salah satu TV satelit yang tidak kalah bersaing dengan yang lain adalah BIG TV. Big TV merupakan salah satu TV satelit dengan channel terbanyak dan termurah di Indonesia, baik SD (standar definition) maupun HD (high definition), sekaligus menjadikannya TV satelit berbayar pertama yang menyajikan saluran HD lebih banyak bagi para konsumennya. Daftar channel Big TV terdiri dari: Entertainment, Movie, Sports, Lifestyle, Education, KIDS, Music, News International, Chinese dan special tiering. Dalam penyediaan channel, Big TV harus mampu bersaing dengan TV satelit yang lain sebagai kompetitornya yaitu indovision, orange TV, k-Vision, Aora TV(operator TV berlangganan Indonesia yang asyknya 24 jam, menyuguhkan acara favorit keluarga dengan harga terjangkau mulai dari 59 ribuan / bulan). Komitmen big TV adalah memberikan tayangan terbanyak, terbaik dengan harga yang ekonomis.

Bagi perusahaan, dalam hal ini operator TV, tanggapan / penilaian konsumen terhadap acara yang disiarkan adalah sangat penting. Penilaian konsumen ini akan mempengaruhi niat konsumen untuk membeli atau tidak membeli suatu produk. Niat merupakan satu faktor internal (individual) yang mempengaruhi perilaku konsumen. Dalam proses pembelian, niat beli konsumen ini berkaitan erat dengan motif yang dimilikinya untuk memakai ataupun membeli produk tertentu. Menurut Theory of Reasoned Action dari Fishbein dan Ajzen, tindakan seseorang adalah realisasi dari keinginan atau niat seseorang untuk bertindak. Faktor yang mempengaruhi niat adalah sikap pada tindakan, dan norma subyektif menyangkut persepsi seseorang, apakah orang lain yang dianggap penting akan mempengaruhi perilakunya. Niat beli masyarakat Kelurahan Sei Agul pada BIG TV yang dipengaruhi Sikap Konsumen dan Norma Subyektif Konsumen menarik untuk diteliti, karena harganya terjangkau dimana produk ini menyediakan paket yang relatif murah dan biaya pemasangan juga relatif murah. Motivasi utama masyarakat membeli BIG TV adalah untuk dapat menikmati siaran-siaran olahraga terutama sepak bola dimana pencinta siaran sepakbola secara umum adalah laki-laki. Supaya semua anggota keluarga dapat menikmati manfaat BIG TV maka operator TV ini juga menediakan acara lain seperti Entertainment, Movie, Sports, Lifestyle, Education, KIDS, Musik dan lain-lain.

Berdasarkan uraian pendahuluan di atas, maka masalah yang dirumuskan dalam penelitian ini sebagai berikut: Apakah sikap konsumen dan norma subyektif berpengaruh signifikan terhadap niat konsumen untuk membeli BIG TV pada Kelurahan Sei Agul Kecamatan Medan Barat. 


\section{MODEL THEORY OF REASONED ACTION}

Setiap orang membawa sumber daya dalam setiap pengambilan keputusan yaitu waktu, uang dan perhatian, umumnya terdapat keterbatasan yang jelas pada kesediaan masing-masing, sehingga memerlukan semacam alokasi yang cermat. Kepercayaan merek, evaluasi merek dan maksud untuk membeli merupakan tiga komponen sikap. Kepercayaan merek adalah komponen konnitif dari sikap. Evaluasi merek adalah komponen afektif atau perasaan. Maksud untuk membeli adalah komponen kognitif atau tindakan. Dari tiga komponen sikap, evaluasi merek adalah pusat dari telaah sikap karena evaluasi merek merupakan ringkasan dari kecenderungan konsumen menyenangi atau tidak menyenangi merek tertentu. Evaluasi merek sesuai dengan definisi dari sikap terhadap merek yaitu kecenderungan untuk mengevaluasi merek baik disegani atau tidak disegani. Model-model sikap yang berkembang akan mempunyai relevansi bagi para pemasar jika model itu mampu memprediksi perilaku konsumen. Dengan perkataan lain, sejauh mana sikap konsumen mampu dijadikan dasar untuk memprediksi perilakunya.

Menurut Setiadi (2005), untuk mengetahui bagaimana sikap bisa memprediksi perilaku konsumen dengan menggunakan teori Reasoned Action dari Fishbein. Theory of reasoned action menggambarkan keterpaduan yang menyeluruh dari komponen sikap dalam struktur yang didesain untuk mengarahkan prediksi dan penjelasan yang lebih baik dari perilaku. Model ini memandang perilaku seseorang sebagai fungsi dari niatnya untuk berperilaku dalam cara tertentu dan variabel penguat lainnya. Niat seseorang untuk membeli suatu produk (BI) dipengaruhi oleh skapnya terhadap perilaku atau tindakan pembelian tersebut (AB) dan norma subyektifnya (SN) dimana persepsi seseorang bahwa orang lain yang penting baginya akan bertindak terhadap perilaku tersebut.

Model ini disajikan pada gambar berikut:

Gambar 1. Theory of Reasoned Action (Teori Tindakan Beralasan)

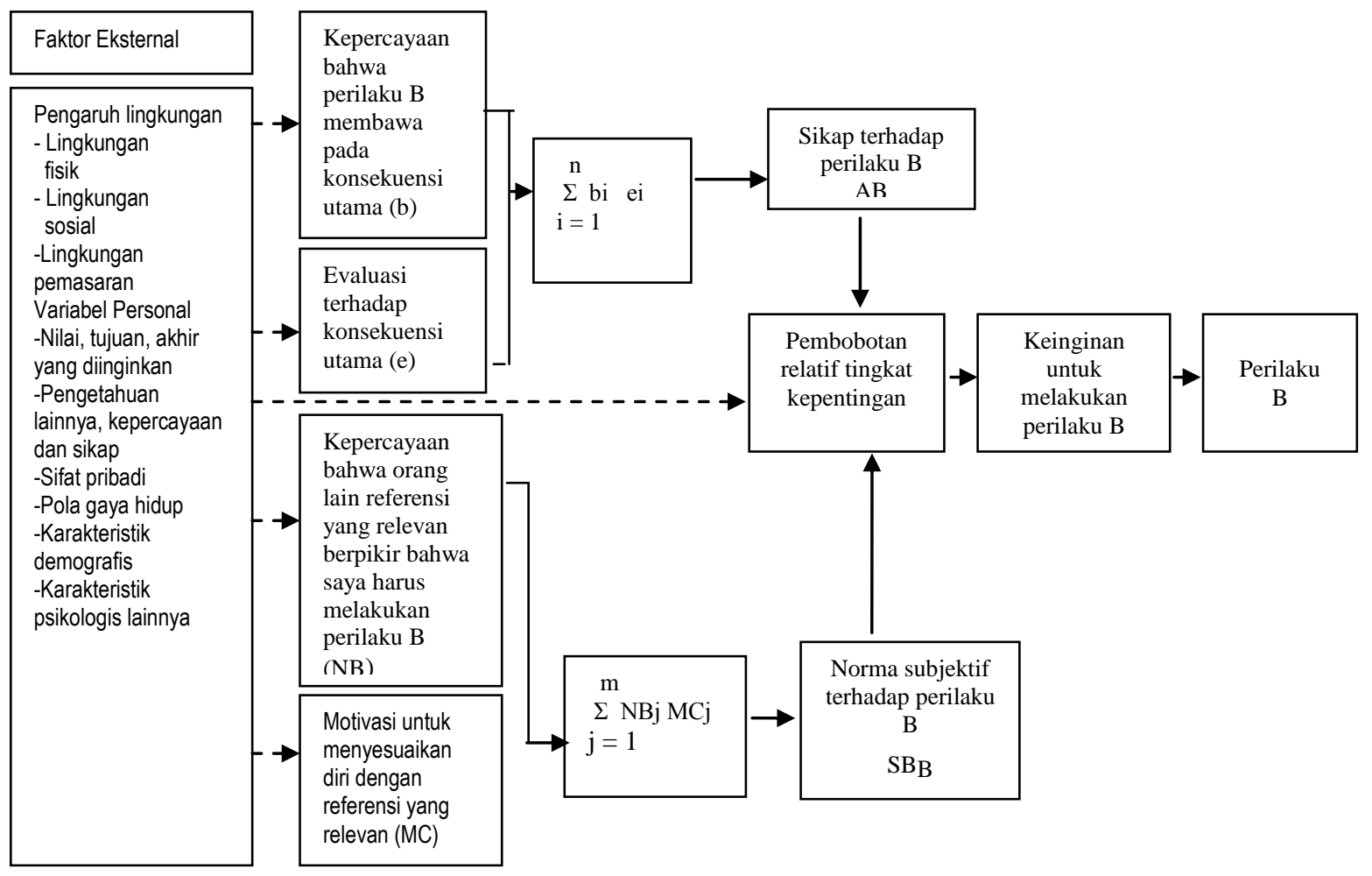

Sumber: Peter dan Olson. Customer Behavior: Perilaku Konsumen dan Strategi Pemasaran, (2006) 
Teori Reasoned Action mampu memprediksi maksud dan perilaku yang dapat diterjemahkan dalam persamaan matematika sebagai brikut (Setiadi, 2005):

$$
\mathrm{A}_{\mathrm{act}} \stackrel{\mathrm{N}}{=} \underset{\mathrm{i}=1}{\mathrm{~N}} \text { bi.ei }
$$

Keterangan:

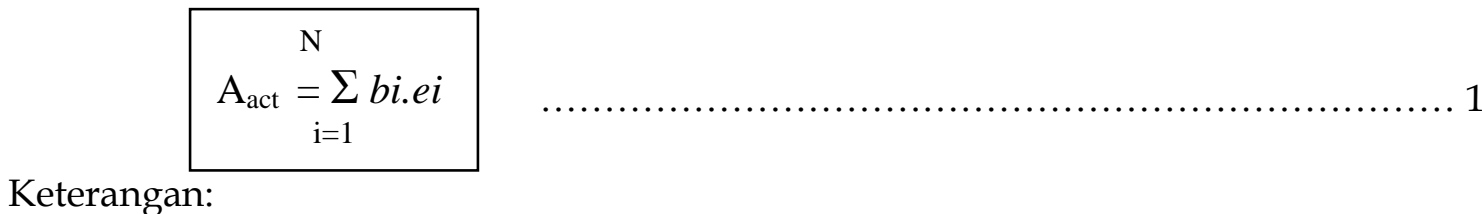

$\mathrm{A}_{\text {act }}=$ Sikap terhadap perilaku

bi =Kepercayaan seseorang yang membentuk perilaku menghasilkan akibat i

ei $\quad=$ Evaluasi seseorang terhadap atribut $\mathrm{i}$

$\mathrm{N} \quad=$ Jumlah kepercayaan

Model Reasoned Action menekankan pada pengukuran sikp yang lebih pada maksud berperilaku. Penilaian kepercayaan pada model Reasoned Action yaitu menilai kepercayaan konsumen yang membentuk perilaku karena lebih memikirkan akibat dari tindakan yang dilakukan.

Motivasi seseorang untuk menuruti pendapat orang lain (preferen) ditentukan oleh kekuatan dari preferen bersangkutan yang dapat diartikan bahwa semakin kuat atau lemah motivasinya untuk menuruti apa yang dikehendaki referen, karakteristik personal dapat diartikan bahwa kesediaan seseorang itu untuk menuruti pendapat referen tertentu pada kepribadian individu yang bersangkutan. Menurut Setiadi (2005), norma subjektif (SN) dapat dihitung dengan rumus:

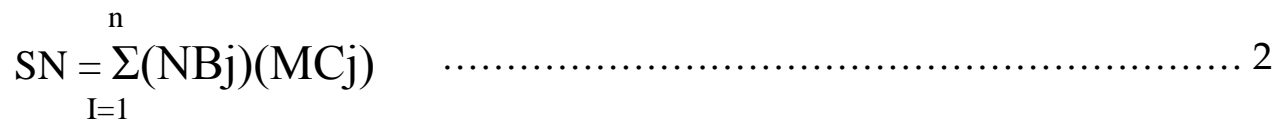

Keterangan: $\quad$ SN = Norma subjektif yang menghendaki perilaku tertentu

$\mathrm{NBj}=$ Keyakinan normatif dari pengaruh kelompok preferen

$\mathrm{MCj}=$ Motivasi menurut preferen

$\mathrm{N} \quad=$ Jumlah responden (jumlah sampel)

Salah satu teori yang biasa menerangkan hubungan antara sikap, minat dan perilaku adalah theory of reasined action yang dikembangkan oleh Fishbein. Menurut teori Reasined Aaction bahwa perilaku seseorang sangat tergantung pada minat/niatnya (intention), sedangkan niat untuk berperilaku sangat tergantung pada sikap (attitude) dan norma subyektif atas perilaku. Pada sisi lain, keyakinan terhadap akibat perilaku dan evaluasi akibat akan menentukan sikap perilaku seseorang. Demikian pula, keyakinan normatif dan motivasi untuk mengikuti pendapat orang lain akan menentukan norma subyektifnya. Secara garis besar dapat disimpulkan bahwa minat untuk berperilaku dipengaruhi oleh faktor internal dan eksternal (lingkungan sosial). Faktor internal tercermin pada sikap seseorang da faktor eksternal tercermin pada pengaruh orang lain terhadap perilaku keputusan yang diambil.

Menurut Peter dan Olson (2006), teori tindakan beralasan (theory of reasoned action) mengasumsikan bahwa konsumen secara sadar mempertimbangkan konsekuensi alternative perilaku yang sedang dipertimbagkan dan memilih salah satu yang dapat memberikan konsekuensi paling diharapkan. Tindakan seseorang terhadap suatu objek tidak harus secara kuat atau tersistematisasi berhubungan dengan perilaku khusus mereka. Sebaliknya, penentu langsung apakah konsumen terlibat dalam perilaku adalah keinginan mereka untuk terlibat dalam perilaku tersebut.

Theory of reasoned action memandang perilaku seseorang sebagai fungsi dari niatnya untuk berperilaku dalam cara tertentu dan variabel penguat lainnya. Niat seseorang untuk 
membeli suatu produk (BI) dipengaruhi oleh sikapnya ( $\left.\mathrm{A}_{\text {act }}\right)$ dan norma subyektifnya (SN) dimana persepsi seseorang dipengaruhi oleh orang lain terhadap perilakunya. Perilaku menggambarkan suatu tindakan nyata terhadap suatu produk atau jasa, maka untuk memprediksi minat berperilaku digunakan persamaan sebagai berikut:

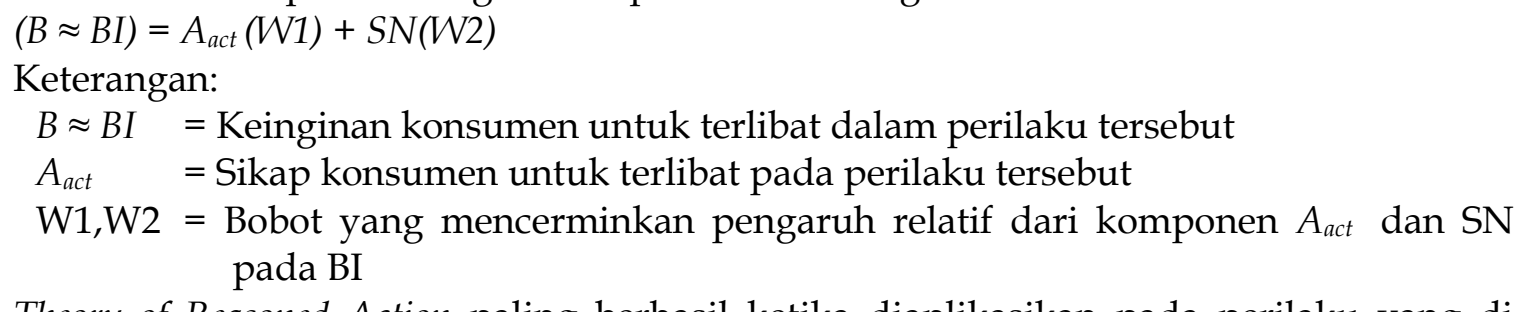

Theory of Reasoned Action paling berhasil ketika diaplikasikan pada perilaku yang di bawah kendali individu sendiri. Jika perilaku tersebut tidak sepenuhnya di bawah kendali atau kemauan individu, meskipun ia sangat termotivasi oleh sikap dan norma sujektifnya, ia mungkin tidak akan secara nyata menampilkan perilaku tersebut.

\section{ANALISIS DATA}

Pendekatan yang digunakan dalam penelitian ini adalah desktiptif kuantitatif. Metode deskriptif yaitu metode yang dilakukan dengan menggunakan data, mengklasifikasikan dan kemudian mengolah, menganalisa serta menafsirkan sehingga memberikan gambaran yang lengkap mengenai fakta yang dikumpulkan. Langkah-langkah analisis adalah :

1. Menghitung nilai persepsi yang diukur dari sikap konsumen dengan rumus :

$$
A_{\text {act }}=\sum_{i=1}^{N} b i . e i
$$

Keterangan:

$\mathrm{A}_{\text {act }}=$ Sikap terhadap perilaku

bi = Kepercayaan seseorang yang membentuk perilaku menghasilkan akibat i

ei $\quad=$ Evaluasi seseorang terhadap atribut $\mathrm{i}$

$\mathrm{n} \quad=$ Jumlah kepercayaan

2. Menghitung nilai preferensi dari norma subyektif (SN) dengan rumus :

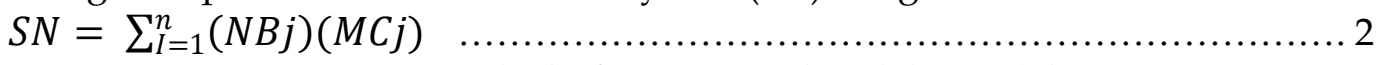

Keterangan: $\mathrm{SN}=$ Norma Subjektif yang menghendaki perilaku tertentu

$\mathrm{NBj}$ = Keyakinan normatif dari pengaruh kelompok preferen

$\mathrm{MCj}=$ Motivasi menurut preferen

$\mathrm{n} \quad=$ Jumlah responden (jumlah sampel)

3. Menghitung persamaan perilaku konsumen dengan rumus sebagai berikut:

$$
\begin{gathered}
(B \approx B I)=A_{\text {act }}(W 1)+S N(W 2) \\
G M A_{\text {act }}=\frac{\text { Total } b_{i}+\text { Total } e_{i}}{2 \times \text { Jumlah atribut }} \text { dimana } G M A_{\text {act }}=\text { Grand Mean } A_{\text {act }} \\
G M S N=\frac{\text { Total Nbj }+ \text { Total } M C j}{2 \times \text { Jumlah atribut }}=\operatorname{dimana~} G M S N=\text { Grand Mean } S N \\
W 1=\frac{G M A_{\text {act }}}{G M A_{\text {act }}+G M S N} \\
W 2=\frac{G M S N}{G M A_{\text {act }}+G M S N}
\end{gathered}
$$

Keterangan :

$\mathrm{B} \approx \mathrm{BI}=$ Keinginan konsumen untuk terlibat dalam perilaku tersebut 
$\mathrm{A}_{\mathrm{act}} \quad=$ Sikap konsumen untuk terlibat pada perilaku tersebut

$\mathrm{SN} \quad=$ Norma subyektif yang menghendaki perilaku tertentu

$\mathrm{W} 1, \mathrm{~W} 2$ = Bobot yang menceriminkan pengaruh relatif dari komponen $\mathrm{A}_{\text {act }}$ dan SN pada BI

Kriteria pengujian skor sikap, norma subyektif terhadap perilaku konsumen untuk membeli digunakan range Henerson sebagai berikut :

$$
\begin{array}{cl}
1,8<\mathrm{Ab} / \mathrm{SN} \leq 3,0 & \text { : Sangat kuat (positif) } \\
0,6<\mathrm{Ab} / \mathrm{SN} \leq 1,8 & : \text { Kuat (positif) } \\
-0,6<\mathrm{Ab} / \mathrm{SN} \leq 0,6 & \text { : Cukup kuat (positif/negatif) } \\
-1,8<\mathrm{Ab} / \mathrm{SN} \leq-0,6 & \text { : Rendah(negatif) } \\
-3,0<\mathrm{Ab} / \mathrm{SN} \leq-1,8 & \text { : Sangat Rendah (negatif) }
\end{array}
$$

\section{HASIL PENELITIAN}

Pengaruh Keyakinan Konsumen (bi) dan Evaluasi akan Akibat (ei) terhadap Sikap Konsumen $(\mathrm{Ab})$

Keyakinan akan Perilaku (bi)

Keyakinan konsumen (bi) merupakan ide yang dianut masyarakat untuk membeli dan

\begin{tabular}{|c|c|c|c|c|c|c|c|c|}
\hline \multirow[t]{2}{*}{ Sub Variabel } & SS & $S$ & AS & ATS & TS & STS & \multirow{2}{*}{$\begin{array}{l}\text { Rata=rata } \\
\text { tertimbang }\end{array}$} & \multirow[t]{2}{*}{ Penilaian } \\
\hline & 3 & 2 & 1 & -1 & -2 & -3 & & \\
\hline Bayaran bulanan gratis untuk & & & & & & & & \\
\hline 6 bulan pertama (b1) & 16 & 58 & 12 & 4 & 5 & 1 & 1.66 & Positif \\
\hline $\begin{array}{l}\text { Biaya pemasangannya } \\
\text { teriangkau (b2) }\end{array}$ & 20 & 47 & 22 & 3 & 3 & 1 & 171 & Positif \\
\hline Banyak pilihan paket (b3) & 18 & 50 & 20 & 2 & 5 & 1 & 1,66 & Positif \\
\hline Variasi tayangan lengkap (b4) & & & & & & & & \\
\hline Sarat edukasi (b5) & 21 & 45 & 23 & 4 & 2 & 1 & 1,72 & Positif \\
\hline $\begin{array}{l}\text { Tayangan olah raga yang } \\
\text { lengkap (b6) }\end{array}$ & 12 & 40 & 28 & 6 & 3 & 1 & 1,34 & Positif \\
\hline $\begin{array}{l}\text { Tayangannya aman untuk } \\
\text { anak-anak (b7) }\end{array}$ & 9 & 34 & 33 & 11 & 8 & 1 & 1,02 & Positif \\
\hline Musik yang lebih lengkap (b8) & 10 & 58 & 17 & 7 & 3 & 1 & 1,53 & Positif \\
\hline $\begin{array}{l}\text { Drama yang berseason dan ada } \\
\text { jedanya (b9) }\end{array}$ & 22 & 45 & 20 & 6 & 2 & 1 & & Positif \\
\hline & 21 & 48 & 20 & 3 & 3 & 1 & 1,74 & Positif \\
\hline Jumlah & - & - & - & - & - & - & 14,08 & - \\
\hline Rata-rata & - & - & - & - & - & - & 1,56 & Positif \\
\hline
\end{tabular}
cenderung menimbulkan konsekuensi dari atribut BIG TV. Berdasarkan skor jawaban responden atas pernyataan-pernyataan menyangkut keyakinan konsumen, dapat dihitung nilai variabel keyakinan akan perilaku seperti ditunjukkan dalam tabel berikut:

Tabel 1. Nilai Variabel Keyakinan Konsumen (bi)

Sumber: Hasil Penelitian tahun 2015 (Data diolah)

Rata-rata tertimbang dihitung dengan cara mengalikan antara total responden yang memilih tiap alternatif jawaban dikali bobot jawaban, kemudian dibagi dengan jumlah responden. Contoh, rata-rata tertimbang b1 yaitu bayaran bulanan gratis selama enam bulan pertama dihitung sebagai berikut: $\{(16 \times 3)+(58 \times 2)+(12 \times 1)+(4 x-1)+(5 x-2)+(1 x-3)\} / 96=1,66$

Arti penilaian sub variabel keyakinan perilaku (bi) sebagai berikut:

1. Nilai sub variabel (b1) sebesar 1,66, berarti konsumen mempunyai keyakinan kuat atau positif terhadap bayaran bulanan yang gratis selama enam bulan sejak pemasangan antena BIG TV. 
2. Nilai sub variabel (b2) sebesar 1,71, berarti konsumen mempunyai keyakinan kuat atau positif terhadap biaya pemasangan BIG TV yang terjangkau.

3. Nilai sub variabel (b3) sebesar 1,66, berarti konsumen mempunyai keyakinan kuat atau positif terhadap pilihan paket yang banyak dari BIG TV.

4. Nilai sub variabel (b4) sebesar 1,72, berarti konsumen mempunyai keyakinan kuat atau positif terhadap variasi tayangan yang lengkap dari BIG TV.

5. Nilai sub variabel (b5) sebesar 1,34, berarti konsumen mempunyai keyakinan kuat atau positif terhadap tayangan BIG TV yang sarat edukasi.

6. Nilai sub variabel (b6) sebesar 1,02, berarti konsumen mempunyai keyakinan kuat atau positif terhadap tayangan olah raga yang lengkap dari BIG TV.

7. Nilai sub variabel (b7) sebesar 1,53, berarti konsumen mempunyai keyakinan kuat atau positif terhadap tayangan BIG TV yang aman untuk anak-anak.

8. Nilai sub variabel (b8) sebesar 1,70, berarti konsumen mempunyai keyakinan kuat atau positif terhadap tayangan music yang lengkap dari BIG TV.

9. Nilai sub variabel (b9) sebesar 1,74, berarti konsumen mempunyai keyakinan kuat atau positif terhadap tayangan drama BIG TV yang berseason dan ada jeda.

Dari uraian di atas diketahui bahwa faktor yang paling dominan mempengaruhi keyakinan perilaku konsumen untuk berlangganan BIG TV adalah biaya pemasangan yang terjangkau, variasi tayangan yang lengkap, music yang lebih lengkap dan drama yang berseasond dan ada jedanya.

\section{Evaluasi akan Akibat (ei)}

Evaluasi akan akibat (ei) menunjukkan penilaian konsumen terhadap atribut keyakinan untuk memasang BIG TV. Berdasarkan skor jawaban responden atas pernyataan-pernyataan menyangkut variabel evaluasi, dapat dihitung nilai variabel evaluasi akan akibat seperti ditunjukkan dalam tabel berikut:

Tabel 2 Nilai Variabel Evaluasi Akan Akibat (ei)

\begin{tabular}{|c|c|c|c|c|c|c|c|c|}
\hline \multirow[t]{2}{*}{ Sub Variabel } & SS & $\mathrm{S}$ & AS & ATS & TS & STS & \multirow{2}{*}{$\begin{array}{l}\text { Rata }=\text { rata } \\
\text { tertimbang }\end{array}$} & \multirow[t]{2}{*}{ Penilaian } \\
\hline & 3 & 2 & 1 & -1 & -2 & -3 & & \\
\hline Bayaran bulanan gratis & 22 & 52 & 13 & 5 & 3 & 1 & 176 & \\
\hline Biaya pemasangannya & & 32 & 10 & $\mathrm{~J}$ & $\mathrm{~J}$ & 1 & 1,10 & 10 sitil \\
\hline terjangkau (e2) & 18 & 53 & 14 & 5 & 5 & 1 & 1,63 & Positif \\
\hline Banyak pilihan paket (e3) & 15 & 40 & 28 & 8 & 2 & 3 & 1,38 & Positif \\
\hline Variasi tayangan lengkap & & & 21 & 8 & 3 & 2 & 137 & Doritic \\
\hline Sarat edukasi (e5) & $\begin{array}{l}14 \\
10\end{array}$ & 51 & 27 & $\begin{array}{l}0 \\
5\end{array}$ & $\begin{array}{l}3 \\
3\end{array}$ & $\begin{array}{l}2 \\
0\end{array}$ & $\begin{array}{l}1,37 \\
1,54\end{array}$ & $\begin{array}{l}\text { Positif } \\
\text { Positif }\end{array}$ \\
\hline Tayangan olah raga yang & & & & & & & & \\
\hline lengkap (e6) & 11 & 45 & 26 & 7 & 4 & 3 & 1,30 & Positif \\
\hline $\begin{array}{l}\text { Tayangannya aman untuk } \\
\text { anak-anak (e7) }\end{array}$ & 12 & 48 & 25 & 8 & 2 & 1 & 1,48 & Positif \\
\hline $\begin{array}{l}\text { Musik yang lebih lengkap } \\
\text { (e8) }\end{array}$ & 17 & 52 & 20 & 5 & 1 & 1 & 1,72 & Positif \\
\hline $\begin{array}{l}\text { Drama yang berseason dan } \\
\text { ada jedanya (e9) }\end{array}$ & 17 & 55 & 13 & 5 & 5 & 1 & 1,63 & Positif \\
\hline Jumlah & & & & & & & 13,81 & - \\
\hline Rata-rata & & & & & & & 1,53 & Positif \\
\hline
\end{tabular}

Sumber: Hasil Penelitian tahun 2015 (Data Diolah)

Arti penilaian sub variabel evaluasi aka akibat (ei) sebagai berikut: 
a. Nilai sub variabel (e1) sebesar 1,76 menunjukkan bahwa konsumen memberikan penilaian kuat atau positif terhadap bayaran bulanan yang gratis selama enam bulan sejak pemasangan antena BIG TV.

b. Nilai sub variabel (e2) sebesar 1,63, berarti konsumen mempunyai penilaian kuat atau positif terhadap biaya pemasangan BIG TV yang terjangkau.

c. Nilai sub variabel (e3) sebesar 1,38, berarti konsumen mempunyai penilaian kuat atau positif terhadap pilihan paket yang banyak dari BIG TV.

d. Nilai sub variabel (e4) sebesar 1,37, berarti konsumen mempunyai penilaian kuat atau positif terhadap variasi tayangan yang lengkap dari BIG TV.

e. Nilai sub variabel (e5) sebesar 1,54, berarti konsumen mempunyai penilaian kuat atau positif terhadap tayangan BIG TV yang sarat edukasi.

f. Nilai sub variabel (e6) sebesar 1,30, berarti konsumen mempunyai penilaian kuat atau positif terhadap tayangan olah raga yang lengkap dari BIG TV.

g. Nilai sub variabel (e7) sebesar 1,48, berarti konsumen mempunyai penilaian kuat atau positif terhadap tayangan BIG TV yang aman untuk anak-anak.

h. Nilai sub variabel (e8) sebesar 1,72, berarti konsumen mempunyai penilaian kuat atau positif terhadap tayangan music yang lengkap dari BIG TV.

i. Nilai sub variabel (e9) sebesar 1,63, berarti konsumen mempunyai penilaian kuat atau positif terhadap tayangan drama BIG TV yang berseason dan ada jeda.

Berdasarkan uraian di atas dapat dilihat bahwa faktor yang dominana mempengaruhi evaluasi masyarakat / konsumen untuk berlangganan BIG TV adalah bayaran bulanan yag gratis selama enam bulan pertama, biaya pemasanga yang terjagkau dan musik yang lebih lengkap.

\section{Keyakinan Normatif (NBj) dan Motivasi (MCj)}

Keyakinan normatif menunjukkan gagasan yang diterima dari kelompok preferen yang berpendapat bahwa seyogyanya atau tidak seyogyanya berlangganan BIG TV. Keyakinan normatif dipengaruhi oleh anggota keluarga, tetangga, teman dekat, rekan kerja, rekan bisnis dan tenaga pemasar.

Berdasarkan skor jawaban responden atas pernyataan-pernyataan menyangkut keyakinan normatif, dapat dihitung nilai variabel keyakina normatif seperti ditunjukkan dalam tabel berikut:

Tabel 3 Nilai Variabel Keyakinan Normatif (NBj)

\begin{tabular}{|l|l|l|l|l|l|l|l|l|}
\hline \multicolumn{1}{|c|}{ Sub Variabel } & SS & S & AS & ATS & TS & STS & Rata-rata & Penilaian \\
\cline { 2 - 8 } & 3 & 2 & 1 & -1 & -2 & -3 & tertimbang & \\
\hline Anggota keluarga (NB1) & 10 & 24 & 30 & 16 & 15 & 3 & 0,53 & Positif \\
Tetangga (NB2) & 11 & 30 & 32 & 14 & 8 & 2 & 1,02 & Positif \\
Teman dekat (NB3) & 9 & 25 & 30 & 15 & 14 & 3 & 0,57 & Positif \\
Rekan kerja (NB4) & 7 & 28 & 24 & 16 & 19 & 2 & 0,43 & Positif \\
Tenaga pemasar (NB5) & 8 & 27 & 22 & 20 & 16 & 3 & 0,41 & Positif \\
\hline Jumlah & & & & & & & 2,96 & \\
\hline Rata-rata & & & & & & & 0,59 & Positif \\
\hline
\end{tabular}

Sumber: Hasil Penelitian tahun 2015 (Data diolah)

Arti penilaian sub variabel keyakinan normative (NBj) adalah:

a. Nilai sub variabel (NB1) sebesar 0,53, berarti konsumen mempunyai keyakinan yang kuat (positif) untuk berlangganan BIG TV karena pengaruh anggota keluarga. 
b. Nilai sub variabel (NB2) sebesar 1,02, berarti konsumen mempunyai keyakinan yang sangat kuat (positif) untuk berlangganan BIG TV karena pengaruh anggota keluarga.

c. Nilai sub variabel (NB3) sebesar 0,57, berarti konsumen mempunyai keyakinan yang kuat (positif) untuk berlangganan BIG TV karena pengaruh teman dekat.

d. Nilai sub variabel (NB4) sebesar 0,43, berarti konsumen mempunyai keyakinan yang cukup kuat (positif) untuk berlangganan BIG TV karena pengaruh rekan kerja.

e. Nilai sub variabel (NB5) sebesar 0,41, berarti konsumen mempunyai keyakinan yang cukup kuat (positif) untuk berlangganan BIG TV karena pengaruh tenaga pemasar.

Dari uraian tersebut, diketahui bahwa variabel yang paling dominan mempengaruhi keyakinan normatif konsumen adalah tetangga, teman dekat dan keluarga. Nilai rata-rata variabel keyakinan normatif sebesar 0,59. Artinya, konsumen diyakinkan oleh kelompok preferen untuk berlangganan BIG TV.

Nilai atribut dari variabel motivasi (MCj) dapat dihitung berdasarkan skor jawaban responden atas pernyataan-pernyataan menyangkut motivasi seperti ditunjukkan dalam tabel berikut:

Tabel 4 Nilai Motivasi (MCj)

\begin{tabular}{|l|l|l|l|l|l|l|l|l|}
\hline \multirow{2}{*}{ Sub Variabel } & SS & S & AS & ATS & TS & STS & Rata-rata & Penilaian \\
\cline { 2 - 9 } & 3 & 2 & 1 & -1 & -2 & -3 & tertimbang & \\
\hline Anggota keluarga (MC1) & 7 & 27 & 31 & 20 & 9 & 2 & 0,65 & Positif \\
Tetangga (MC2) & 8 & 35 & 23 & 24 & 5 & 1 & 0,75 & Positif \\
Teman dekat (MC3) & 9 & 19 & 28 & 21 & 15 & 1 & 0,43 & Positif \\
Rekan kerja (MC4) & 8 & 27 & 25 & 24 & 19 & 3 & 0,33 & Positif \\
Tenaga pemasar (MC5) & 7 & 24 & 22 & 26 & 21 & 1 & 0,21 & Positif \\
\hline Jumlah & & & & & & & 2,37 & \\
\hline Rata-rata & & & & & & & 0,47 & Positif \\
\hline
\end{tabular}

Sumber: Hasil Penelitian tahun 2015 (Data diolah)

Arti penilaian sub variabel motivasi (MCj) sebagai berikut:

a. Nilai sub variabel (MC1) sebesar 0,65, artinya masyarakat / konsumen mendapat motivasi kuat (postif) dari anggota keluarga untuk berlangganan BIG TV.

b. Nilai sub variabel (MC2) sebesar 0,75, artinya masyarakat / konsumen mendapat motivasi kuat (postif) dari tetangga untuk berlangganan BIG TV.

c. Nilai sub variabel (MC3) sebesar 0,43, artinya masyarakat / konsumen mendapat motivasi cukup kuat (postif) dari teman dekat untuk berlangganan BIG TV.

d. Nilai sub variabel (MC4) sebesar 0,33, artinya masyarakat / konsumen mendapat motivasi cukup kuat (postif) dari rekan kerja untuk berlangganan BIG TV.

e. Nilai sub variabel (MC5) sebesar 0,21, artinya masyarakat / konsumen mendapat motivasi kuat (postif) dari tenaga pemasar untuk berlangganan BIG TV.

Dari uraian di atas dapat dilihat bahwa variabel yang paling dominan mempengaruhi motivasi masyarakat / konsumen untuk berlangganan BIG TV adalah anggota keluarga dan tetangga.

Berdasarkan tabel 5.10 diketahui, nilai rata-rata variabel motivasi (MCj) sebesar 0,47. Artinya, masyarakat / konsumen mendapat dorongan yang positif (cukup kuat) dari kelompok preferen untuk berlangganan BIG TV 


\section{Sikap Konsumen}

\section{PEMBAHASAN}

Sikap konsumen $(\mathrm{Ab})$ dihitung dengan mengalikan antara nilai sub variabel keyakinan perilaku (bi) denga nilai sub variabel evaluasi akan akibat (ei). Berdasarkan tabel 5.7 dan tabel 5.8 dapat dihitung nilai sikap konsumen seperti pada tabel berikut:

Tabel 5 Nilai Sikap Konsumen (Ab)

\begin{tabular}{|l|l|l|l|l|}
\hline Indikator penelitian & $\begin{array}{l}\text { Keyakinan } \\
\text { perilaku (bi) }\end{array}$ & $\begin{array}{l}\text { Evaluasi } \\
\text { akan akibat } \\
(\mathrm{ei})\end{array}$ & $\begin{array}{l}\text { Ab }= \\
\text { bi x ei }\end{array}$ & Penilaian \\
\hline Bayaran bulanan gratis untuk 6 & 1,66 & 1,76 & 2,92 & Positif \\
bulan pertama (Ab1) & 1,71 & 1,63 & 2,79 & Postif \\
Biaya pemasangannya & 1,66 & 1,38 & 2,29 & Positif \\
terjangkau (Ab2) & 1,72 & 1,37 & 2,36 & Positif \\
Banyak pilihan paket (Ab3) & 1,54 & 2.06 & Positif \\
Variasi tayangan lengkap (Ab4) & 1,34 & 1,30 & 1,33 & Positif \\
Sarat edukasi (Ab5) & 1,02 & 1,48 & 2,26 & Positif \\
Tayangan olah raga yang lengkap & 1,53 & 1,72 & 2,92 & Positif \\
(Ab6) & 1,70 & 1,63 & 2,84 & Positif \\
Tayangannya aman untuk anak- & & & \\
anak (Ab7) & 1,74 & 13,81 & 21,77 & - \\
Musik yang lebih lengkap (Ab8) & & 1,53 & 2,42 & Positif \\
Drama yang berseason dan ada & & 14,08 & 1,56 &
\end{tabular}

Sumber: Hasil Penelitian tahun 2015 (Data diolah)

Arti penilaian sub variabel sikap konsumen (Abi) sebagai berikut:

a. Nilai sub variabel (Ab1) sebesar 2,92, artinya masyarakat / konsumen mempunyai sikap positif (kuat) terhadap bayaran bulanan yang gratis selama enam bulan sejak pemasangan BIG TV.

b. Nilai sub variabel (Ab2) sebesar 2,79, artinya masyarakat / konsumen mempunyai sikap positif (kuat) terhadap biaya pemasangan BIG TV yang gratis

c. Nilai sub variabel (Ab3) sebesar 2,29, artinya masyarakat / konsumen mempunyai sikap positif (kuat) terhadap banyaknya pilihan paket BIG TV.

d. Nilai sub variabel (Ab4) sebesar 2,36, artinya masyarakat / konsumen mempunyai sikap positif (kuat) terhadap variasi tayangan lengkap dari BIG TV.

e. Nilai sub variabel (Ab5) sebesar 2,06, artinya masyarakat / konsumen mempunyai sikap positif (kuat) terhadap tayangan yang sarat edukasi.

f. Nilai sub variabel (Ab6) sebesar 1,33, artinya masyarakat / konsumen mempunyai sikap positif (kuat) terhadap tayangan olahraga yang lengkap.

g. Nilai sub variabel (Ab7) sebesar 2,26, artinya masyarakat / konsumen mempunyai sikap positif (kuat) terhadap tayangan yang aman untuk anak-anak.

h. Nilai sub variabel (Ab8) sebesar 2,92, artinya masyarakat / konsumen mempunyai sikap positif (kuat) terhadap musik yang lebih lengkap. 
i. Nilai sub variabel (Ab9) sebesar 2,84, artinya masyarakat / konsumen mempunyai sikap positif (kuat) terhadap drama yang berseason dan ada jeda.

Berdasarkan uraian di atas, diketahui nilai rata-rata variabel sikap konsumen sebesar 2,42. Artinya, masyarakat / konsumen mempunyai sikap positif (kuat) terhadap BIG TV.

\section{Norma Suyektif (SN)}

Norma subyektif (SN) dihitung dengan mengalikan antara nilai sub variabel keyakinan normatif (NBj) dengan nilai sub variabel motivasi (MCj). Berdasarkan tabel 5.9 dan tabel 5.10, dapat dihitung nilai norma subyektif seperti tabel berikut:

Tabel 6 Nilai Norma Subyektif (SN)

\begin{tabular}{|l|l|l|l|l|}
\hline Indikator penelitian & $\begin{array}{l}\text { Keyakinan } \\
\text { normatif } \\
(\mathrm{NBj})\end{array}$ & $\begin{array}{l}\text { Motivasi } \\
(\mathrm{MCj})\end{array}$ & $\begin{array}{l}\mathrm{SN}= \\
\mathrm{NBj} \times \mathrm{MCj}\end{array}$ & Penilaian \\
\hline Anggota keluarga (SN1) & 0,53 & 0,65 & 0,34 & Positif \\
Tetangga (SN2) & 1,02 & 0,75 & 0,77 & Positif \\
Teman dekat (SN3) & 0,57 & 0,43 & 0,25 & Positif \\
Rekan kerja (MC4) & 0,43 & 0,33 & 0,14 & Positif \\
Tenaga pemasar (MC5) & 0,41 & 0,21 & 0,09 & Positif \\
\hline Jumlah & 2,96 & 2,37 & 1,58 & - \\
\hline Rata-rata & 0,59 & 0,47 & 0,32 & Positif \\
\hline
\end{tabular}

Sumber: Hasil penelitian tahun 2015 (Data diolah)

Arti penilaian sub variabel norma subyektif (SNi) sebagai berikut:

a. Nilai sub variabel (SN1) sebesar 0,34, berarti mayarakat / konsumen diyakinkan dan dimotivasi cukup kuat (positif) dari aggota keluarga untuk berlangganan BIG TV.

b. Nilai sub variabel (SN2) sebesar 0,77, berarti mayarakat / konsumen diyakinkan dan dimotivasi kuat (positif) dari tetangga untuk berlangganan BIG TV.

c. Nilai sub variabel (SN3) sebesar 0,25, berarti mayarakat / konsumen diyakinkan dan dimotivasi cukup kuat (positif) dari teman dekat untuk berlangganan BIG TV.

d. Nilai sub variabel (SN4) sebesar 0,14, berarti mayarakat / konsumen diyakinkan dan dimotivasi cukup kuat (positif) dari rekan kerja untuk berlangganan BIG TV.

e. Nilai sub variabel (SN1) sebesar 0,09, berarti mayarakat / konsumen diyakinkan dan dimotivasi cukup kuat (positif) dari tenaga pemasar untuk berlangganan BIG TV.

Berdasarkan uraian di atas, diketahui nilai rata-rata variabel norma subyektif sebesar 0,32. Artinya, masyarakat / konsumen berlangganan BIG TV karena diyakinkan dan mendapat motivasi cukup kuat (positif) dari kelompok preferen.

\section{Perilaku Konsumen (BI)}

Berdasarkan skor jawaban responden terhadap pernyataan, yang telah diolah pada uraian sebelumnya, diperoleh total $\mathrm{bi}=1.182$, total ei $=1.144$, total $\mathrm{NBj}=148$, total $\mathrm{MCj}=130$. Dengan demikian dapat dihitung W1 dan W2 sebagai berikut:

$$
\begin{aligned}
G M A b & =\frac{\text { Total }_{i}+\text { Total } e_{i}}{2 \times \text { Jumlah atribut }}=\frac{1.182+1.144}{2 \times 9}=129,22 \\
\text { GMSN } & =\frac{\text { Total NBj }+ \text { Total } M C j}{2 \times \text { Jumlah atribut }}=\frac{148+130}{2 \times 5}=27,8
\end{aligned}
$$




$$
W 1=\frac{G M A b}{G M A b+G N S W}=\frac{129,22}{129,22+27,8}=0,8229
$$

Dengan demikian diperoleh persamaan minat berperilaku (BI) sebagai berikut:

$$
\begin{aligned}
& \begin{aligned}
W 2= & \frac{G M S N}{G M A b+G M S N}=\frac{27,8}{129,22+27,8}=0,1770 \\
(\mathrm{~B}=\mathrm{BI}) & =\mathrm{W} 1 \mathrm{Ab}+\mathrm{W} 2 \mathrm{SN} \\
& =0,8229 \mathrm{AB}+0,1770 \mathrm{SN}
\end{aligned}
\end{aligned}
$$

Dari persamaan di atas dapat dilihat bahwa ternyata perilaku masyarakat/ konsumen untuk berlanggaan BIG TV lebih besar dipengaruhi oleh sikap konsumen yaitu sebesar 0,8229 atau $82,29 \%$ dibanding norma subyektif, yaitu sebesar 0,1770 atau 17,70\%.

Pembahasan variabel penelitian yang terdiri dari tiga sub variabel diuraikan sebagai berikut: Nilai rata-rata variabel keyakinan akan perilaku sebesar 1,56. Artinya, masyarakat / konsumen mempunyai keyakinan positif yang kuat untuk berlangganan BIG TV. Nilai rata-rata variabel evaluasi akan akibat sebesar 1,53. Artinya, masyarakat/ konsumen memberikan evaluasi yang positif yang kuat untuk berlangganan BIG TV. Nilai rata-rata variabel sikap konsumen $(\mathrm{Ab})$ sebesar 2,42. Artinya, masyarakat/ konsumen bersikap positif sangat kuat terhadap BIG TV.

Nilai rata-rata variabel norma subyektif (NBj) sebesar 0,59. Artinya, masyarakat/ konsumen berlangganan BIG TV karena mempunyai keyakinan yang kuat dari kelompok preferen. Nilai rata-rata variabel motivasi (MCj) sebesar 0,47. Artinya, masyarakat/ konsumen mendapat dorongan yang cukup kuat dan positif dari kelompok preferen untuk berlangganan BIG TV. Rata-rata nilai variabel norma subyektif (SN) sebesar 0,32. Artinya, masyarakat / konsumen diyakinkan dan mendapat motivasi positif dancukup kuat dari kelompok preferen.

Berdasarkan persamaan perilaku: $\mathrm{B}=\mathrm{BI}=0,8229 \mathrm{AB}+0,1770 \mathrm{SN}$, perilaku masyarakat / konsumen untuk berlangganan BIG TV lebih besar dipengaruhi oleh sikap konsumen, yaitu sebesar 0,8229 atau 82,29\% dibanding pengaruh norma subyektif sebesar 0,1770 atau 17,70\%.

Berdasarkan uraian tersebut disimpulkan bahwa sikap dan norma subyektif berpengaruh terhadap perilaku masyarakat di di Kelurahan Sei Agul Kecamatan Medan Barat untuk berlangganan BIG TV.

\section{KESIMPULAN}

Nilai rata-rata variabel sikap konsumen $(\mathrm{Ab})$ sebesar 2,42. Artinya, masyarakat/kon sumen di Kelurahan Sei Agul bersikap positif (sangat kuat) terhadap BIG TV.

Nilai rata-rata variabel norma subjektif (SN) sebesar 0,32. Artinya, masyara kat/konsumen di Kelurahan Sei Agul diyakinkan dan mendapat motivasi positif (cukup kuat) dari kelompok preferen untuk berlagganan BIG TV.

Persamaan niat perilaku: $\mathrm{BI}=0,8229 \mathrm{Ab}+0,1770 \mathrm{SN}$. Perilaku masyarakat/konsu men di Kelurahan Sei Agul untuk berlangganan BIG TV lebih besar dipengaruhi oleh sikap konsumen yaitu sebesar 0,8229 ( 82,29\%) dibanding norma subjektif, yaitu sebesar

$0,1770(17,70 \%)$. 